\title{
Analysis of Community Behavior in Coronavirus Disease-19 Prevention in Medan
}

Rina Amelia ${ }^{1 *}$, Juliandi Harahap ${ }^{1}$, Arlinda Sari Wahyuni ${ }^{1}$, Isti Ilmiati Fujiati ${ }^{1}$, Yuki Yunanda ${ }^{1}$, Putri Chairani Eyanoer ${ }^{1}$, Hendri Wijaya ${ }^{2}$, Reni Asmara Ariga ${ }^{3}$

${ }^{1}$ Department of Community Medicine, Public Health, Faculty of Medicine, Universitas Sumatera Utara, Medan, Indonesia; ${ }^{2}$ Department of Paediatrics, Faculty of Medicine, Universitas Sumatera Utara, Medan, Indonesia; ${ }^{3}$ Faculty of Nursing, Universitas Sumatera Utara, JI. Prof. Maas No. Kampus USU Medan 20155, Indonesia

Edited by: Sasho Stolesk Citation: Amelia R, Harahap J, Wahyuni AS, Fujiati II. Citation: Amelia R, Waranda Eyanoer PC, Wijaya H. Analysis of Community Behavior in Coronavirus Disease-19 Prevention in Medan Open Access Maced J Med Sci. 2020 Sep 25; 8(T1):382-386. Keywords: Coronavirus disease-19; Behavior; Prevention

*Correspondence: Rina Amelia, Department of Community Medicine/Public Health, Faculty of Medicine Universitas Sumatera Utara, Jl. dr. Mansyur No. 5 Kampus USU Medan 20155, Indonesia. E-mail: rina2@usu.ac.id Received: 24-Jul-2020 Accepted: $15-$ Sep-2020 Copyright: ๑) 2020 Rina Amelia, Juliandi Harahap, Arlind Sari Wahyuni, Isti llmiati Fujjati, Yuki Yunanda, Putri Chairani Eyanoer, Hendri Wijaya Funding: Publication of this article was financially supported by the Scientific Foundation SPIROSKI, Skopje, Republic of Macedonia Competing Interests: The authors have declared that no
competing interests exist Competing Interests: The authors have declared that no
competing interests exist

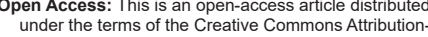
under the terms of the Creative Commons Attribution-
NonCommercial 4.0 International License (CC BY-NC 4.0)

\begin{abstract}
BACKGROUND: Coronavirus (CoV) is a type of virus that can cause interference with the respiratory tract. The development of CoV disease (COVID)-19 is happening fast in the world, especially in Indonesia. In Medan, the highest number of COVID-19 cases was spread in the Medan Selayang sub-district. One of the steps taken by the government to reduce transmission of COVID-19 is by implementing prevention and social distancing behavior Community behavior is influenced by various factors such as age, sex, physical nature, level of education, and socioeconomic to culture.
\end{abstract}

AIM: The aim of this study was to find out the factors that influence the community behavior of Medan Selayang people in the effort to prevent COVID-19.

METHODS: This cross-sectional study was conducted on 102 respondents. Data collection methods, in the form of primary data, are carried out by distributing and filling out questionnaires through the Google form media.

RESULTS: One hundred two respondents were found that $90.2 \%$ of respondents had good behavior in COVID-19 prevention efforts. The multinomial logistic regression found sig. $(\mathrm{P})$ on the variables of gender, age, education level, and employment status, respectively, $0.360,0.772,0.860$, and $0.878(p>0.05)$

CONCLUSIONS: In this study, no significant relationship was found between sex, age, education level, and employment status on COVID-19 preventive behavior.

\section{Introduction}

Coronavirus $(\mathrm{CoV})$ is a type of virus that can cause interference with the respiratory tract. CoV consists of several types, such as severe acute respiratory syndrome CoV (SARS-CoV) and Middle East Respiratory Syndrome-related CoV (MERS-CoV). The most recent CoV found in China is the 2019 CoV Novel (2019nCoV) [1]. On December 31, 2019, the World Health Organization (WHO) China Country Office reported a case of pneumonia of unknown etiology in Wuhan City, Hubei Province, China. On January 7, 2020, China identified pneumonia of unknown etiology as a new type of CoV (nCoV). Then, on January 30, 2020, the WHO established the disease by this virus as a Public Health Emergency of International Concern/World-Anxious Public Health Emergency (KKMMD). On February 12, 2020 , the WHO officially determined that this novel human CoV would be called the CoV disease 2019 (COVID-19). COVID-19 is caused by SARS-CoV-2 which belongs to the same large family of CoV as the cause of SARS in 2003 , only with different types of viruses [2].
The development of the COVID-19 case was rapid. The COVID-19 case in Indonesia was initially found in Depok, West Java, but has now spread to 34 other provinces.1. In North Sumatra, COVID-19 cases also continue to increase, especially in the city of Medan. As of May 16, 2020, the number of people under monitoring (PUM) was 1171 people, asymptomatic cases (ASC) were 1125 people, patients under surveillance (PDP) was 526 people, and COVID19 positive patients were 147 people. This amount is spread, especially in the district of Medan Selayang which is one of the red zones in Medan [3].

In dealing with the COVID-19 pandemic, a number of strategies and steps have been taken by the government to be able to suppress transmission of COVID-19, one of which is by applying prevention and social distancing behavior. Social distancing to be able to reduce or even break the chain of COVID-19 infection is done by maintaining a safe distance between individuals/other human beings that are at least as far as $2 \mathrm{~m}$, not in direct contact with others, and avoiding mass gatherings as for a number of Indonesian people not responding to this well. School entertainment or the 
application of work at home, which were implemented by the government some time ago with the aim of reducing transmission, were used by the community for vacation. In addition, there are also Indonesian people who underestimate the pandemic of this virus and do not heed the government's appeals; as a result, the addition of cases of COVID-19 continues to occur [4].

Balkhi et al., in his study, found that during the COVID-19 pandemic, some concerned populations in Karachi, Pakistan, made behavioral changes [5]. Behavior is a form of response or reaction to stimuli or stimuli from outside organisms (people), but in providing this response very dependent on the characteristics or other factors of the person concerned [6]. The factors that play a role include such as age, sex, physical nature, level of education, socioeconomic to culture.

The attitude or behavior showed by the phenomenon above, as well as remembering quite a number of cases of COVID-19 in the Medan Selayang sub-district, encouraging the writer to analyze further regarding the behavior of the people of Medan Glance in the face of a pandemic COVID-19, especially in efforts to prevent COVID-19.

\section{Methods}

This research is analytic research with a cross-sectional research method conducted in Medan Selayang district, Medan, during the period from MayJune 2020.

\section{Study population and sampling}

The population of this study is all people who live in Medan Selayang District. The sample is done by consecutive sampling, that is, all samples that come and meet the inclusion criteria are included in the study until the minimum number of subjects is met. The inclusion criteria consisted of (1) people who live in the Medan Selayang sub-district, (2) people aged $\geq 17$ years, and (3) people who are willing to take part in the research. The minimum sample size needed in this study is 102 respondents, which are determined through three steps, namely, (1) determining the sample size of each independent variable studied, (2) rules of thumb, and (3) rules of thumb with correction.

\section{Study tool}

Data collection, in the form of primary data, is obtained through filling out questionnaires through Google form. A questionnaire is a data collection technique that is done by giving a set of questions or written statements to respondents to be answered. The questionnaire used by researchers is to refer to the Likert scale, and validity and reliability tests have been performed.

\section{Statistical analysis}

The data collected will then be carried out a series of processes ranging from editing, coding, entry, cleaning, and saving. Then, the data will be processed and analyzed using the SPSS (Statistical Package for the Social Sciences) computer program. Data analysis begins descriptively to see the characteristics of the data. To see the effect of gender, age, level of education, and employment status on behavior, a logistic regression test was performed. Data are presented in the form of a frequency distribution table.

\section{Ethical consideration}

All the participants agreed to the study procedures and expressed their willingness to all in the Google Form, which was sent through WhatsApp.

\section{Results}

Based on research conducted in the Medan Selayang sub-district during the period of May to June, 2020, 102 respondents who met the inclusion and exclusion criteria were met.

Characteristics of research respondents. The total respondents obtained in the study were 102 respondents. The characteristics of respondents are shown in Table 1:

Table 1: Characteristics of research respondents in Medan Selayang

\begin{tabular}{lll}
\hline Characteristic & Frequency (person) $\mathrm{n}=102$ & Percentage \\
\hline Gender & 38 & 37.5 \\
$\quad$ Male & 64 & 62.7 \\
$\quad$ Female & & \\
Age (years) & 71 & 69.6 \\
17-25 & 16 & 15.7 \\
$26-35$ & 11 & 10.8 \\
$36-45$ & 4 & 3.9 \\
$46-55$ & 0 & 0 \\
$55-65$ & 0 & 0 \\
$>65$ & 0 & \\
Level of education & 3 & 2.9 \\
Primary school & 35 & 34.3 \\
Junior high school & 64 & 62.7 \\
Senior high school & & \\
Bachelor & 29 & 28.4 \\
Employment status & 73 & 71.6 \\
$\quad$ Still working & & \\
Not working & & \\
\hline
\end{tabular}

The table above described the characteristics of respondents consisting of 38 male respondents (37.3\%) and 64 respondents' women (62.7\%). Based on age, the highest number of respondents was those with age range $17-25$ years with 71 respondents (69.6\%), and the least respondents were with the age range 46-55 years with four respondents $(3.9 \%)$. In this study, there 
were no respondents in the age range above 55 years. The table also describes other characteristics, namely, the level of education and employment status at the time of the pandemic. Based on the level of education, it was found that the highest number of respondents with a bachelor's level of education (64 people; $62.7 \%$ ) and the least was respondents with a junior high school/ equivalent level of 3 people (2.9\%). Based on the current employment status of the pandemic, 29 respondents were still working $(28.4 \%)$, and 73 respondents were not working $(71.6 \%)$.

The factors studied were gender, age, level of education, and employment status. Each factor is assessed and divided into three categories of behavior, namely, poor, neutral, and good.

In Table 2, it is showed that $90.2 \%$ of respondents have good behavior in the prevention of COVID-19, only $9.8 \%$ of respondents behaved neutral, and no respondents were found to behave poorly.

Table 2: Distribution of COVID-19 prevention behaviors in Medan Selayang

\begin{tabular}{lll}
\hline Behavior & Frequency (person) $\mathrm{n}=102$ & Percentage \\
\hline Neutral & 10 & 9.8 \\
Good & 92 & 90.2 \\
\hline COVID: Coronavirus disease. & &
\end{tabular}

Table 3 shows that good prevention behavior is more prevalent among respondents in the 17-25 years age group (91.5\%). While based on gender, good prevention behavior was found more in women $(92.2 \%)$ compared to men $(86.8 \%)$. The majority of respondents have education levels up to the bachelor level, with good preventive behavior shown by $89.1 \%$ of graduates. Respondents with good preventative behavior were also found in the group of high school/ vocational/equivalent graduates which are around $91.4 \%$. The majority of respondents who do not work have good preventive behavior $(91.7 \%)$. In contrast to respondents who were still working, good preventive behavior was shown by 25 of the total 29 respondents working (86.2\%).

Table 3: Distribution of behavioral factors in an effort to prevent COVID-19

\begin{tabular}{lllll}
\hline Characteristic & \multicolumn{2}{l}{ Behavior } & Jumlah & $\mathrm{p}$ \\
\cline { 2 - 3 } & Good & Neutral & & \\
\hline Gender & $33(86.8)$ & $5(13.2)$ & $38(100)$ & 0.360 \\
$\quad$ Male & $59(92.2)$ & $5(7.8)$ & $64(100)$ & \\
$\quad$ Female & $65(91.5)$ & $6(8.5)$ & $71(100)$ & 0.772 \\
Age (years) & $14(87.5)$ & $2(12.5)$ & $16(100)$ & \\
$\quad 17-25$ & $9(81.8)$ & $2(18.2)$ & $11(100)$ & \\
$26-35$ & $4(100)$ & 0 & $4(100)$ & \\
$36-45$ & $3(100)$ & 0 & $3(100)$ & 0.860 \\
$\quad 46-55$ & $32(91.4)$ & $3(8.6)$ & $35(100)$ & \\
Level of education & $57(89.1)$ & $7(10.9)$ & $64(100)$ & \\
$\quad$ Junior high school & & & & \\
$\quad$ Senior high school & & & \\
$\quad$ Bachelor & $25(86.2)$ & $4(13.8)$ & $29(100)$ & 0.878 \\
Employment status & $67(91.8)$ & $6(8.2)$ & $73(100)$ & \\
$\quad$ Still working & & & & \\
$\quad$ Not working & & &
\end{tabular}

Apart from the results of the above research, a multinomial logistic regression test was also carried out to find out the factors that influence the behavior of the people of Medan Selayang in their efforts to prevent COVID-19. The analysis shows the value of sig. (P) in each independent variable $(p>0.05)$ - this value indicates that in this study, there were no independent variables (factors of gender, age, level of education, and employment status) which statistically significantly influences the dependent variable (behavior).

\section{Discussion}

This study aims to look at the effect of several demographic variables, namely, age, sex, education level, and employment status, on prevention behavior toward COVID-19 disease. From the research data collected, $90.2 \%$ of respondents have good preventive behavior toward COVID-19. After analysis, the four factors studied (independent variables of the study) did not have a statistically significant effect on COVID-19 disease prevention behavior.

In the previous studies, gender was considered to have an influence on preventive behavior [7], [8]. In a study by Yildirim et al., women had better preventive behavior and statistically had significant differences with men. In addition to having better preventive behavior, women are also considered to have a better risk perception and have a higher fear [8]. This was also shown by Shahnaz et al., which found significant differences between men and women [7]. Clinically, men tend to have worse cases when compared to women. This is also in line with the higher mortality in men compared to women [9]. Clinically, age has an influence on the severity and mortality of COVID-19 disease. In a meta-analysis study, an exponential increase in mortality risk was found in the age group above 50 years in patients with COVID-9 [10]. This is also consistent with findings of higher infection susceptibility, as well as worse clinical manifestations found in patients with older age [10], [11]. In a study conducted by Atchison et al., age was assessed as having an influence significant toward preventive behavior, especially the adoption of social distancing actions. Research data show that people aged $>70$ years have a positive association with social distancing when compared with young adults aged 18-34 years [12]. While in a study in Hong Kong that assessed the adoption of social distancing has not shown statistically significant differences, however, based on the regression analysis conducted on the study data, it shows that the odds ratio of OR decreases with age, although not significantly [13].

In the education level variable, several studies have shown a significant effect of education level on preventive behavior in COVID-19. Research by Atchison et al. assesses the influence of education level on work from home behavior that is associated with total income. It was shown that respondents with better levels of education had higher incomes and savings compared to respondents with lower levels 
of education, making it difficult to do work from home. Meanwhile, the differences in prevention based on education level did not differ too much. Prevention measures differed more based on the socio-economic status of the respondents. Respondents with lower levels of education were judged to have a lower ability and desire to isolate themselves compared to higher levels of education [12]. Other studies have shown that education levels have an influence on preventive actions, but do not specifically explain preventive actions that are judged differently [8].

In addition to the education level variable, the researcher also assessed the employment status. In the previous studies, employment status was grouped into more specific subcategories such as working full time (30 hours or more), working part-time, full-time students, retiring, not working, or unemployed. One study showed employment status as demographic data; in the research data, the researcher more closely related the amount of income and socioeconomic status with preventive measures [12]. In another study by Kwok et al., no significant differences were found between subcategories of employment status but found odds the highest ratio that is for pensioners and workers [13].

In contrast to some previous studies which showed a significant relationship on several factors that influence preventive behavior toward COVID-19, based on data collected in this study, no significant relationship was found between the variables studied (gender, age, education level, and employment status) toward preventive behavior toward COVID-19. The difference in the results of this study can be caused by the presence of other factors that are more instrumental in the formation of COVID-19 prevention behavior in the Medan Selayang community. Some other factors that can influence the behavior of the people of Medan Selayang, especially in efforts to prevent COVID-19, include public trust (fear of infection), the presence or absence of chronic diseases (diabetes mellitus, hypertension, heart disease, or lung disease), and the level of socioeconomic.

At present, there are many and adequate sources of information about COVID-19 so that public knowledge of COVID-19 should be good enough. People's fears of a pandemic are one of the factors that result in better preventive behavior. Besides the things mentioned above, the differences in the results of this study can also be caused by the limitations of researchers, especially in sampling in the pandemic era, where the distribution of questionnaires is done through online media which are difficult to monitor and are less effective to reach affordable populations [14]. This limitation, coupled with the narrow duration of sampling, causes the number of research samples collected to be small so that the samples obtained are also less variable. Apart from the above circumstances, this research has been carried out for a long time since the first case was announced so that the behavior of the community is likely not the same as when the pandemic began. Therefore, the researcher recommends further research, both by involving the variables above and by including other variables such as community trust, comorbid disease, and socioeconomics. In addition, researchers also suggest taking more samples with an adequate time span.

\section{Conclusions}

In this study, no significant relationship was found between sex, age, education level, and employment status on COVID-19 preventive behavior. As in the previous studies, a significant relationship can be found in some of these variables. This may be influenced by other factors, such as the availability of adequate sources of information and public fear of this pandemic. The difference in the results of this study can also be caused by the minimal number of samples involved in this study due to the short duration of the study. For this reason, we recommend further research by taking more samples with an adequate time span, and by involving other variables such as community trust, comorbid disease, and socioeconomics.

\section{References}

1. Kementerian Kesehatan Republik Indonesia (KEMENKES RI). Pedoman Pencegahan dan Pengendalian Coronavirus Disease (COVID-19); 2020. Available from: https://www.kemkes.go.id. [Last accessed on 15 May 2020].

2. Kementerian Dalam Negeri. Pedoman Umum Menghadap Pandemi COVID-19 Bagi Pemerintah Daerah (Pencegahan, Pengendalian, Diagnosis dan Manajemen); 2020. Available from: https://www.kemendagri.go.id/documents/covid-19/ BUKU_PEDOMAN_COVID-19_KEMENDAGRI.pdf. [Last accessed on 2020 May 15]. https://doi.org/10.15408/sjsbs. v7i7.15512

3. Pemerintah Kota Medan. Tim Gugus Tugas Percepatan Penanganan COVID-19. PEMKO Medan; 2020. Available from: https://www.covid19.pemkomedan.go.id. [Last accessed on 2020 May 16].

4. Yildirim M, Gecer E, Akgul O. The impacts of vulnerability, perceived risk, and fear on preventive behaviours against COVID-19. Psychol Health Med. 2020;2020:4-7. https://doi.org/ 10.1080/13548506.2020.1776891

PMid:32490689

5. Jin J, Bai P, He W, Wu F, Liu X, Han D, et al. Gender differences in patients with COVID-19: Focus on severity and mortality. Front Public Health. 2020;8:152.

PMid:32411652

6. Bonanad C, Garcia-Blas S, Tarazona-Santabalbina F, Sanchis J, Bertomeu-Gonzalez V, Facila L, et al. The effect of age on mortality in patients with Covid-19: A metanalysis with 611,583 
subjects. J Am Med Direct Assoc 2020;21(7):915-8. https://doi. org/10.1016/j.jamda.2020.05.045

7. Liu Y, Mao B, Liang S, Yang JW, Lu HW, Chai YH, et al. Association between age and clinical characteristics and outcomes of COVID-19. Eur Respir J. 2020;55(5):1-3.

8. Atchison C, Bowman L, Vrinten C, Redd R, Pristera P, Eaton J, et al. Perceptions and behavioural responses of the general public during the COVID-19 pandemic: A cross-sectional survey of UK adults. MedRxiv. 2020;2020:1-17. https://doi. org/10.1101/2020.04.01.20050039

9. Kwok K, Li K, Chan H, Yi Y, Tang A, Wei W, et al. Community responses during the early phase of the COVID-19 epidemic in Hong Kong: Risk perception, information exposure and preventive measures. MedRxiv. 2020;2020:1-13. https://doi. org/10.1101/2020.02.26.20028217

10. Buana DR. Analisis perilaku masyarakat Indonesia dalam menghadapi pandemi virus corona (Covid-19) dan kiat menjaga kesejahteraan jiwa. SALAM J Sosial Budaya Syari.
2020;7:15082. https://doi.org/10.15408/sjsbs.v7i3.15082

11. Balkhi F, Nasir A, Zehra A, Riaz R. Psychological and behavioral response to the coronavirus (COVID-19) pandemic. Cureus. 2020;12(5):e7923. https://doi.org/10.7759/cureus.7923

12. Saifuddin A. Metode Penelitian. Yogyakarta: Pustaka Pelajar; 2016.

13. Shahnazi $H$, Ahmadi-Livani $M$, Pahlavanzadeh $B$, Rajabi $A$, Shoaib $\mathrm{H}$, Charkazi A. Assessing preventive health behaviors from COVID-19 based on the health belief model (HBM) among people in Golestan Province: A cross-sectional study in Northern Iran. Res Square. 2020;2020:6-10. https://doi.org/10.21203/ rs.3.rs-24871/v1

14. Sari DK, Amelia R, Dharmajaya R, Sari LM, Fitri NK. Positive correlation between general public knowledge and attitudes regarding COVID-19 outbreak 1 month after first cases reported in Indonesia. J Community Health. 2020;2020:1-8. https://doi. org/10.21203/rs.3.rs-35827/v1

PMid:32583360 